Manuscript Number: JCLEPRO-D-17-00194R2

Title: University Culture and Sustainability: Designing and Implementing an Enabling Framework

Article Type: Original article

Keywords: University sustainability; Organizational culture;

Environmental accountability; Wicked problem

Corresponding Author: Dr. Richard Adams,

Corresponding Author's Institution:

First Author: Richard J Adams, MA MBA PhD

Order of Authors: Richard J Adams, MA MBA PhD; Stephen Martin; Katy Boom

Abstract: Universities across the globe are giving increasing priority to the challenges of sustainability, encouraged by a variety of drivers including international and national policy, student and societal pressures. Many extant initiatives focus on a relatively narrow set of activities including: Technological solutions; Integrating sustainability across the curriculum; Integrating sustainability as an operational, strategic and outreach principle. These have met with mixed success, and have overlooked the importance of cultural change in embedding sustainability. Drawing and building upon previous studies in the cultural change and sustainability literature, the purpose of this article is to propose a conceptual framework for designing interventions and measuring and monitoring progress in building and embedding a university sustainability culture. Initial staff and student survey data from a UK university has been applied to the framework and their interpretation and implications are explored. 


\title{
University Culture and Sustainability: Designing and Implementing an Enabling Framework
}

Richard Adams (corresponding author)

Reader in Entrepreneurship, Bettany Centre for Entrepreneurship, Cranfield School of Management, Cranfield, UK

Email: correspond.adams@btinternet.com

Phone: +44 (0)1234 751122

Stephen Martin

Honorary Professor, University of Worcester; Visiting Professor, University of the West of England, UK

Email: esm@esmartin.demon.co.uk

Phone: +44 (0)1386 832806

Katy Boom

Director of Sustainability, University of Worcester, Worcester, UK

Email: k.boom@worc.ac.uk

Phone: +44 (0)1905 855243

\section{Word count}

- Paper excluding references and appendix 7,690

- Paper including references and appendix 11,468 words

\begin{abstract}
Universities across the globe are giving increasing priority to the challenges of sustainability, encouraged by a variety of drivers including international and national policy, student and societal pressures. Many extant initiatives focus on a relatively narrow set of activities including: Technological solutions; Integrating sustainability across the curriculum; Integrating sustainability as an operational, strategic and outreach principle. These have met with mixed success, and have overlooked the importance of cultural change in embedding sustainability. Drawing and building upon previous studies in the cultural change and sustainability literature, the purpose of this article is to propose a conceptual framework for designing interventions and measuring and monitoring progress in building and embedding a university sustainability culture. Initial staff and student survey data from a UK university has been applied to the framework and their interpretation and implications are explored.
\end{abstract}

\section{KEYWORDS}

University sustainability; Organizational culture; Environmental accountability; Wicked problem 


\section{INTRODUCTION}

Universities and Higher Education Institutes (HEIs) have been amongst the earliest signatories to sustainability declarations, beginning in 1972 with the Stockholm Declaration on the Human Environment and later the Talloires Declaration (UNESCO, 1990), the first statement by university administrators of a commitment to sustainability in higher education (Wright 2002). As of January 2016, the Declaration had been signed by 499 university presidents and chancellors at institutions in 54 countries $^{1}$. The American College \& University Presidents Climate Commitment ${ }^{2}$ has in excess of 650 members and the Association for the Advancement of Sustainability and Higher Education ${ }^{3}$ over 750. The Higher Education Sustainability Initiative (HESI) was created as a partnership of United Nations entities in the run-up to the UN's Conference on Sustainable Development (Rio+20). With a global membership of almost 300 universities, HESI accounts for more than one-third of all the voluntary commitments that came out of Rio +20 .

In recent decades, then, many universities and HEls have aligned themselves to the principles of sustainability. The role that universities have to play in the transformation toward a more sustainable society is attested to in both the scholarly and practitioner literature (Trencher, Bai, Evans et al., 2014; Ramos, Caeiro, van Hoof et al., 2015). Typically, their sustainability-related initiatives consist of academic, operational and wider stakeholder outreach activities (Luna and Maxey 2013; Shiel, Filho, do Paço et al., 2016), For example, there has been considerable effort expended in: the re-design of curricula (Beusch, 2014; Martin, McCoshan \& McEwen, 2014); in greening campuses (Brinkhurst, Rose, Maurice et al., 2011; ISCN Secretariat, 2014); and, building local, regional and international networks to influence behaviour (Arbo and Benneworth, 2007; Bansal, Bertels, Ewart et al., 2012). At the same time, universities have been exploring and developing the means to integrate and embed enduring sustainability thinking. Efforts have included such initiatives as: establishing institutional guidelines and frameworks; reifying sustainability as the lived on-campus life experience (e.g. campus as a living lab); and, maintaining programmes of sustainability audits for example using the Auditing Instrument for Sustainability in Higher Education (Shriberg 2002; Wright, 2007; McCoshan and Martin 2013; Marans, Callewaert \& Shriberg, 2015; Lozano, Lukman, Lozano et al., 2013).

Notwithstanding such activity, progress has been criticised for being technologically opportunistic and lacking overall coordination, leadership and coherence (Ramos et al., 2015; ISCN Secretariat 2014; Butt, More, \& Avery 2014; Martin, Dillon, Higgins, et al., 2013), leaving some of the bigger questions relating to sustainability, such as the social dimension, unaddressed (Bone and Agombar, 2011) and, notably, a lack of enduring effects (Cotton and Alcock, 2013).

It is clear that the "embedding of sustainability in higher education has been far from straightforward...[and that]... that implementation has been patchy - both in terms of disciplinary spread and in terms of the understandings of sustainability" (Cotton and Alcock, 2013: 1458). A culture for sustainability can be thought of as "one in which organizational members hold shared assumptions and beliefs about the importance of balancing economic efficiency, social equity and environmental accountability" (Bertels, Papania \& Papania, 2010: 10), and the failure to embed sustainability in HEls suggests it has failed to become part of the culture.

This observation finds support from UNESCO's (2006: 3) call “to integrate the values inherent in sustainable development into all aspects of learning" (authors' emphasis), and Trencher et al's (2014) that most barriers to university partnerships for urban sustainability are human rather than technical. If universities and HEls are to deliver on their promise of providing tomorrow's leaders,

\footnotetext{
${ }^{1}$ Source: Association of University Leaders for a Sustainable Future http://www.ulsf.org/programs talloires signatories.html\#UK, June 2016

${ }^{2}$ http://secondnature.org/

${ }^{3} \mathrm{http}: / / \mathrm{www}$.aashe.org/.
} 
managers, scientists and teachers with the knowledge and cognitive skills to address the challenges of sustainability, then these shortcomings need to be addressed.

The purpose of this article is to address this gap by proposing and piloting a conceptual framework to guide the development, implementation and monitoring of a university culture for sustainability reflecting diverse stakeholder communities, including: students, staff (academic), staff (nonteaching) and, stakeholder businesses in the local community. The article begins by briefly locating the challenge of sustainable culture as a 'wicked problem' (Churchman 1967). Following that, two streams of literature, organizational culture and sustainable transformation are reviewed and integrated for the purpose of proposing a conceptual framework to help monitor and accelerate embedding a culture for sustainability. Next, the framework is applied in the context of the case of University of Worcester's sustainability journey, and draws comparisons to others' efforts in the field. The article concludes with a discussion of next steps and reflections on implications for theory and practice. Consequently, this article is about 'becoming' sustainable and, as such, marks a departure in the $\mathrm{HEI} /$ Sustainability literature which, to date, has tended to focus on HEls as change agents, sustainability pedagogy and campus-based, incremental, technological innovation for resource efficiency and optimization, and so raises important debate regarding embedding change holistically within HEI culture.

\section{UNIVERSITY SUSTAINABILITY CULTURE AS A WICKED PROBLEM}

The whole notion of sustainability is inherently complex, made so through the integration of three high level considerations - people, planet, profit (Elkington 1997) - and long-time horizons with hard to quantify impacts (Epstein and Roy 2001). The journey towards sustainability is mired in this complexity and so characteristically a 'wicked problem' - wicked in the sense of often being illformulated, cutting across boundaries, being highly resistant to resolution, constituted by multiple agents and decision makers with conflicting values, and with ramifications for the whole system (Churchman 1967). Becoming sustainable is, consequently, a challenging problem in terms of communicating and controlling its characteristic values, behaviours and attributes to guide actor and institutional behaviour (Martin and Murray 2011). On these grounds, there are several reasons why a university's journey to sustainability can be thought of as a wicked problem, as summarised in Table 1.

\section{Table 1: The wicked problems of universities' transitions to sustainability}

\begin{tabular}{|c|c|c|}
\hline Problem & Description & Illustrative literature \\
\hline $\begin{array}{l}\text { Complex network } \\
\text { of internal and } \\
\text { external } \\
\text { stakeholders }\end{array}$ & $\begin{array}{l}\text { Diverse areas of activity are involved in universities' } \\
\text { transitions to sustainability, including: learning and teaching, } \\
\text { operations, external engagement and research, as well as } \\
\text { what is done and how it is done. Cuts across social, economic } \\
\text { and organizational boundaries and involves multiple agents } \\
\text { many of whom are accustomed to high levels of autonomy. } \\
\text { The complexity is such that universities are frequently likened } \\
\text { to small cities, where decisions have long-lasting and wide- } \\
\text { scale ramifications. }\end{array}$ & $\begin{array}{l}\text { Alshuwaikhat and } \\
\text { Abubakar (2008); } \\
\text { Hoover and Harder } \\
\text { (2014) }\end{array}$ \\
\hline Evaluating impact & $\begin{array}{l}\text { Cost-benefit calculations are highly complex: for example, } \\
\text { how can a university's impact on living and non-living natural } \\
\text { systems and on social systems be measured, and over what } \\
\text { time frame? Further, the challenge of changing 'ecological } \\
\text { world views' through educative processes should not be } \\
\text { under-estimated, particularly as what constitutes requisite } \\
\text { sustainability competencies remains unclear. }\end{array}$ & $\begin{array}{l}\text { Barth et al. (2016); } \\
\text { Corcoran, Weakland } \\
\text { and Wals, (2017); } \\
\text { Lukman and Glavič } \\
\text { (2007); Richardson } \\
\text { and Lynes (2007) }\end{array}$ \\
\hline $\begin{array}{l}\text { Systemic } \\
\text { approaches }\end{array}$ & $\begin{array}{l}\text { Lengthening the glide path through incremental innovation } \\
\text { (i.e. squeezing more from limited resources) is an insufficient }\end{array}$ & Adams, Jeanrenaud, \\
\hline
\end{tabular}




\begin{tabular}{|l|l|l|}
\hline required & solution; more systemic approaches are required. & Bessant et al. (2016). \\
\hline Role of universities & $\begin{array}{l}\text { What is the 'system' and what is a university's place within } \\
\text { that system? Do universities ignite, accelerate or block } \\
\text { change? }\end{array}$ & $\begin{array}{l}\text { Brennan, King \& } \\
\text { Lebeau (2004) }\end{array}$ \\
\hline Legacy issues & $\begin{array}{l}\text { Transitions to sustainability rendered challenging due to } \\
\text { incumbents historically running unsustainably and so } \\
\text { constrained by legacy of organizational culture and may } \\
\text { require of institutions new generations of governance } \\
\text { approaches orientated to the long-term. }\end{array}$ & $\begin{array}{l}\text { Hoover and Harder } \\
\text { (2014); Hamann and } \\
\text { April (2013) }\end{array}$ \\
\hline $\begin{array}{l}\text { Contested evidence } \\
\text { base }\end{array}$ & $\begin{array}{l}\text { Can consensus of need for and direction of action be } \\
\text { expected in a context where there remains some (though } \\
\text { diminishing) contestation over the evidence base }\end{array}$ & Whitmarsh (2011) \\
\hline
\end{tabular}

As noted above, a number of universities have publicly declared their intent by committing to initiatives like the Talloires Declaration (UNESCO, 1990), in which university leaders mobilise internal and external resources toward the objective of incorporating sustainability and environmental literacy in operations/strategy and outreach as well as in teaching and research (Wright 2002).

Typically, approaches to the challenge in the university context have been described (ISCN Secretariat 2014) as:

- Technological solutions to sustainability challenges

- Integrating sustainability subject matters across the curriculum

- Integrating sustainability as a core strategic principle across the campus

Reflecting on these efforts, and evaluating the progress of sustainability in higher education, the scholarly literature has noted a predominant focus on technological and operational activities and relatively little attention to strategic and reflexive activities. Further, the literature is characterised by a focus on descriptive studies of specific initiatives, and a preponderance of prescriptive studies that often call on universities to play a more prominent role (e.g. Stephens and Graham, 2010).

Technological solutions have been developed and applied principally in the area that has become known as 'campus greening' (Shriberg and Tallent, 2003; Finlay and Massey, 2012). The idea of the sustainable campus has taken hold in universities across the globe and is reflected in a range of initiatives that include the International Sustainable Campus Network ${ }^{4}$, University of Maryland's Smart and Sustainable Campus Conference ${ }^{5}$, the Association for the Advancement of Sustainability and Higher Education ${ }^{6}$, and the Sustainable Campus International Competition ${ }^{7}$. These initiatives have been successful in raising the challenge across a global audience, acting as living laboratories to design and test innovative technologies and approaches, and in providing a virtuous circle connecting teaching, research and practice. Technological solutions include initiatives such as the design of smart buildings ${ }^{8}$ (McGibbon, Ophoff \& Van Belle, 2015), investing in recycling programmes (Kaplowitz, Yeboah, Thorp et al., 2009) and the promotion of energy saving technology (AASHE, 2014).

\footnotetext{
${ }^{4}$ http://www.international-sustainable-campus-network.org/

${ }^{5}$ http://sustainability.umd.edu/content/community/SSCC.php

${ }^{6}$ http://www.aashe.org/.

${ }^{7}$ http://sustainablecampusic.com/

${ }^{8}$ for example, LEED (Leadership in Energy and Environmental Design) provides certification pathways structured for organizations seeking certification for multiple buildings such as university campuses. See http://www.usgbc.org/leed
} 
Although scholarship acknowledges the contribution technological advances have made to helping move toward a sustainable world, for example in terms of maximising material and energy efficiency (Bocken, Short, Rana et al., 2014), technical solutions alone are not enough. The effects of these initiatives are not being felt either as strongly or quickly as hoped for at their conception, and have been less impactful than designed for in helping universities reach sustainability (Cotton and Alcock, 2013; McCoshan and Martin, 2013). Alongside these, behaviour and systems level change are needed (Adams et al., 2016; Ramos et al., 2015). OECD (2009), too, emphasise the need to move beyond the technical to issues of behaviour and culture, implying that the sustainable organization will remain elusive until, at least, sustainability becomes embedded within the culture of the organization. The agenda has therefore advanced to consider the university more holistically in terms of its transformation and to embed sustainability more deeply into the its structures, processes, practices and culture.

Change models for sustainability in HEls have been limited in their scope and narrow in their vision. Velazquez, Munguia, Platt et al's (2006) conceptualisation and model of the sustainable university goes further than most. It comprises of a four-phase process that moves from strategic to operational activity:

- Phase one: developing a sustainability vision for the university

- Phase two: the mission, the who, what, and why for future actions

- Phase three: enact a sustainability committee to create policies, targets, and objectives

- Phase four: sustainability strategies in four domains of activity, including education, research, outreach and partnership and campus sustainability

Despite its apparent holism, that it can act as a framework for integrating sustainability within institutions as well as in terms of relations with external stakeholders and the wider community, this model is limited. In particular, it would appear to represent a very top down formulation and so contradict the prescriptions of scholars such as Lozano (2006) and Verhulst and Lambrechts (2014) who commend strategies that include bottom-up approaches. Further, it overlooks the important dimension of culture whose important role in change management and transformation initiatives is well established (Armenakis, Brown \& Mehta, 2011).

If universities and HEls are to fulfil their potential role as exemplary organizations, as technical, cognitive and cultural role models of sustainability for this and the next generation's students and leaders as well as into the wider stakeholder community they need to "undergo significant cultural change and transformation" (Linnenluecke and Griffiths 2010: 357) which implies a change of attitude and developing a new set of values and behaviours: in short, an organizational culture for sustainability.

In the following sections, a framework for university sustainability culture is proposed and subsequently reflectively applied on the University of Worcester's continuing journey to sustainability.

\section{CONCEPTUALISING A UNIVERSITY CULTURE OF SUSTAINABILITY}

\subsection{SUSTAINABILITY}

Organizational sustainability is a recently emergent concept that integrates a diversity of intellectual and pragmatic influences. Some scholars have traced its roots back to the socially-informed practices of industrial dynasties most famously, at least in the UK, including the Bourneville and Cadbury families (Lamming, Faruk, \& Cousins 1999; Smith 2003), and, in the USA, to include the likes of Henry Ford (Diamond 2005). In the context of Victorian England, the work of Sir Titus Salt has become recognised as a contemporary exemplar. Having amassed a fortune from weaving together alpaca wool with a silk or cotton warp to create a cloth of the finest quality, Salt moved his mill and workers out of Bradford (then, the most polluted town in England) to build a new industrial community, the 
eponymous town of Saltaire. Salt built 850 houses for his workers, each served with fresh water from Saltaire's own reservoir. He also built shops, schools and Sunday schools, baths, washhouses, almshouses, a club and institute, a Wesleyan chapel, a magnificent Congregational church and a park (Ingham, 2006).

More recent influences include Osborn's (1948) Our Plundered Planet, Carson's (1962) Silent Spring, The World Commission on Environment and Development's Our Common Future (WCED 1987) as well as studies of anthropogenic influence purported to threaten the stability of planetary boundaries (Rockström, Steffen, Noone et al., 2009) that support the ecosystem services on which the world's population depends to survive and thrive (Costanza, d'Arge, de Groot et al., 1997) and on persistent social injustice and inequality (Raworth 2012). There are multiple definitions of sustainability, but the idea of sustainable development as defined in the Brundtland report (WCED, 1987) - "development that meets the needs of the present without compromising the ability of future generations to meet their own needs" - (and variations of it) is commonly adopted as is Elkington's (1997) conceptualisation of the Triple Bottom Line in which organizations are exhorted to adopt a responsible approach and give equivalence to environmental, social and economic dimensions in decision-making.

However, many scholars have argued that becoming and being a sustainable organization is not a singular 'before and after' event, rather it is a process of transformation that takes place over time. Frequently, the journey metaphor has been invoked to describe this (Mohrman and Worley 2010). With exceptions - for example Verhulst and Lambrechts (2014) who describe the integration of sustainable development at KHLeuven as happening in four stages, starting with a bottom-up approach characterised by local micro-initiatives, gradually becoming more prominent and inclusive through the university and moving toward embedding sustainability vision, strategy and behaviour throughout the university - the journey or transformation perspective is not well reflected in the $\mathrm{HEI} /$ Sustainability literature. However, the organizational sustainability literature provides some useful models from which lessons to inform framework development can be drawn.

For organizations that want to become and be sustainable, a dynamic model is required, one that portrays change taking place over time (see Kolk and Mauser (2002) for a review), from Hunt and Auster's (1990) five stages of environmental management (Beginner; Firefighter; Concerned Citizen; Pragmatist; Pro-activist) to, more recently, Adams et al's (2016) transformatory model of three contexts of the sustainability journey (Operational Optimization; Organizational Transformation; Systems Building), the latter resulting from the synthetic processes of systematic review.

In this article, sustainability is conceived as a journey recognisable as a set of transformatory stages in which the behaviour and attitudes of groups of people within an organization become increasingly aligned around and consistent with the principles embodied in and implied by sustainable development. The culture of an organization provides a sense of identity, it is central to the sense of 'who we are as an organization' and makes consistent and coherent organizational action possible (Jacobs et al., 2013). Drawing on Adams et al's (2016) sustainability journey framework provides the means to map progress longitudinally (Box 1 ).

\subsection{ORGANIZATIONAL CULTURE}

Organizational culture is a well-established, influential and, sometimes, controversial concept in management research and practice. The notion of 'culture' as applied to organizations originates in the fields of anthropology and sociology, where there exist various interpretations of its meaning as there do in management and organization studies (Smircich 1983; Tierney 1988). Although variously conceptualised, culture is generally taken to reflect the idea that groups of people - in assemblages of different size - share, in common, a specific set of ideas, norms, values, beliefs and understandings and that these become manifest in and are reinforced by and in the routines, practices, symbols and stories of their community. These manifestations are more or less observable at different 'layers' of the group or organization and, importantly, govern the way in which people 
and the group/organization work. Organizational cultures provide a sense of identity, 'who we are', and are also a representation of behaviour and practice 'how things get done around here'. The link between behaviour and culture appears to be reciprocal, each reinforcing and shaping the other (Schneider and Barbera 2014; Bertels, Papania, and Papania 2010).

\section{Box 1: Three contexts of the sustainability journey (after Adams et al. (2016))}

Operational Optimization: an internally oriented perspective on sustainability, referring to guiding a set of values described as a 'doing the same things but better' approach in which there is a focus on efficiency and compliance with regulation. Typically, technical solutions applied incrementally and in isolation, are the favoured solution to sustainability challenges.

Organizational Transformation: represents a fundamental shift in mind-set in the organization, a shift in values from 'doing less harm' to creating shared value and delivering wider benefits for society by 'doing good by doing new things'. The context is characterized by a redefinition of internal and external relationships that increasingly are conceived in terms of environmental and social impacts. Typically, activities are more people oriented in that they engage with behaviours and attitudes, more deeply integrate sustainability within the organization and are less insular. It remains largely internally oriented, suffusing and diffusing sustainability throughout the organization, but extends to immediate stakeholders too. Sustainability moves beyond compliance and efficiency-motivated initiatives to become embedded in organizational DNA.

Systems Building: extends the notion of sustainability beyond the boundaries of the organization and reflects a radical shift in philosophy and values to thinking beyond the firm and reframing the purpose of organization in society, as 'doing good by doing new things with others'. A key feature is that sustainability cannot logically be thought of as an attribute of a single organization, but can only properly be applied at the systems level which puts external linkages at its core. The context is characterized by a shift toward networks of relations in which sustainability value is created collaboratively rather than individually and firms shift from existing in isolation and in competition to integrated collaborations, with the potential to bring systems-shaping change In terms of sustainability, it can be seen as the 'set of actions that shift a system - a city, a sector, an economy - onto a more sustainable path'.

Schein $(1985,9)$ defines organizational culture as "a pattern of basic assumptions-invented, discovered, or developed by a given group as it learns to cope with its problems of external adaptation and internal integration - that has worked well enough to be considered...the correct way to perceive, think, and feel in relation to those problems." In other words, organizational culture is a collection of values and norms that are shared by people in an organization which governs members' behaviours and actions in pursuit of organizational goals. It is clear then, with behaviours and actions on the one hand and values on the other, that the notion of culture challenges the researcher and change agent to consider tangible, overt as well as less visible instantiations of the phenomenon.

\subsubsection{Visible and invisible culture}

Schein (1997) described three levels of culture: artefacts; espoused values; and, assumptions. These range from overt outward manifestations to deep underlying taken-for-granted, invisible elements that drive organizational action. Schein is not unique in decomposing culture into the visible and invisible, but many scholars favour a simple dichotomy.

For example, Kotter and Heskett (2011) recognise two levels which differ in their visibility and, as a result, their proclivity to change efforts, as does Wilson (2001). The visible level of culture includes group behaviours and actions, which are more observable and easier to measure and change. The invisible level is made up of shared values that tend to persist over time and are self-evidently less visible and so less amenable to change. The latter are the result of the continuing enactment of the 
former. Consequently, the process of changing the deeply-seated, implicit beliefs and assumptions changing a mission statement or reward structures. Both levels of culture are relevant to conceptions of sustainability culture. Organizations looking to build sustainability values into their culture embark on what can be a slow process of ideological transformation in which the underlying assumptions of behaviour are recalibrated through changes to what Linnenluecke, Russell \& Griffiths (2009: 435) describe as 'the observable culture', the visible organizational structure, processes and behaviours (Kagan 2014; Crittenden, Crittenden, Ferrell et al., 2011). That is, over time, change in the visible layer can lead to change in the invisible layer (Kotter and Heskett 2011). The more visible the cultural artefacts, the easier they are to change and the less visible the culture the more resistant the culture is to change, but it is in the less visible aspects that culture is truly embedded.

\subsubsection{Single and multiple cultures}

In addition to visible and invisible elements, some researchers have argued that within a single organization multiple sub-cultures can co-exist (e.g. Linnenluecke, Russell, and Griffiths 2009; Schein 1985). These may be occupationally-, geographically-, hierarchically- or functionally-based. Clark (1983), for example, proposed three levels of culture in higher education: the culture of the discipline, the culture of the enterprise, and the culture of the academic profession and/or national system.

At the organizational level, universities share some similarities with other complex organizations such as companies, government entities, and non-governmental organizations such as being structured with managers and employees (Stephens and Graham, 2010). However, the tradition of academic freedom and the relatively short-term, repeating turnover of students can give rise to these people feeling less invested in institutional culture.

Our focus is at the organizational level within which some researchers are divided as to whether or not multiple sub-cultures aggregate into a coherent, single culture. Schein (1985) argues that if the organization has a significant shared history, then it will have an overall culture. Conversely, and in a study specifically of the university sector, Silver (2003), echoing Cohen, March \& Olsen 's (1972) notion of 'organized anarchy', argues that universities do not have 'a' culture but are better characterised by conflict and lack of coherence. Others describe this more benignly as 'academic culture', one that is characterised by high levels of individual autonomy in teaching and research (Dill, 2012).

On this basis, multiple sub-cultures can be anticipated to co-exist within an HEl each potentially holding different attitudes and orientations toward sustainability which are distinct from those of other sub-cultures. Within universities (Tierney 1988) cultural influences occur at many levels, within departments, across categories of employee, between staff and students. The framework will focus on student, academic, non-teaching and external stakeholder sub-cultures. Levy and Marans (2012) led an interdisciplinary team that developed recommendations grounded in education, assessment and monitoring among students, faculty and staff for building a culture of environmental sustainability on the campus at the University of Michigan. At the University of Guelph in Canada, Brinkhurst et al. (2011) explored the role of leadership for environmental sustainability. In particular they focused on leadership roles of the institutional "middle", faculty and staff, finding intrapreneurial behaviour within this cohort significantly contributing to reaching sustainability objectives, but under-celebrated and under-acknowledged.

Our multiple stakeholder approach, in contrast to previous studies that have focused on academic disciplines (Clark 1983), or tribes (Becher and Trowler 2001), recognises students, teaching faculty, non-teaching staff and external organizational partners as important stakeholders. In recognising the possibility of sub-cultures with potentially different attitudes to and perceptions of sustainability the proposed framework is located in the 'differentiation' stream of culture research (Martin 2015; Martin, Frost, and O'Neill 2006). 
The visible/invisible dichotomy in instantiations of cultural phenomena is reflected in a related debate about whether or not culture is something that organizations are or have. Previous scholarship has differentiated and separated these perspectives, and the roots of the separation lie in the distinct disciplinary ontologies relating to culture: the anthropological perspective (organizations are cultures) and a sociological perspective (organizations have cultures) (Cameron and Quinn 2011).

Both the visible/invisible and the are/have dimensions have significant implications for issues of methodology. The advantage of quantitative approaches is that they make a fuzzy field more accessible on a range of pre-determined salient factors and for promoting generalizability - the organizations have culture dimension. However, quantitative approaches can be criticised for failing to uncover and elaborate those deeper, underlying, hidden aspects of culture that may be idiosyncratic to organizations (the are dimension) and for which qualitative approaches and their resultant thick descriptions (Geertz 1973) are more apposite (Smircich 1983; Cooke and Szumal 1993). As Kwan and Walker (2004: 22) note:

From the is (are) perspective, each organizational culture is unique and only qualitative methods can fully account for this uniqueness [...] the has (have) perspective considers culture as an organizational variable and that it can influence or be influenced by other variables within organizations. (authors' emphasis)

By integrating the are and have perspectives it is possible to interrogate the different layers of organizational culture and to begin to map the trickle-down that initiatives at the visible and influenceable artefact layer have at the more opaque and less accessible basic assumptions level. Consequently, the article's approach looks to combine both quantitative and qualitative methods, the former to focus on the artefacts of culture - the 'visible products' of the organization (Schein 1997) examples of which can include curricula, formal policies, office arrangements, architecture, documentation, language, technology employed, activities and so forth. The latter looks at basic assumptions, root metaphors, stories, symbols and rituals that are implicit and unconsciously guide individual and collective behaviour. This has implications for monitoring the progress for embedding a sustainability culture, suggesting an approach, like organizational culture itself, and working at two levels: a quantitative (survey) approach to tap into the observable aspects of culture and a qualitative (observational/ethnographic) approach to tap into subconscious aspects.

Culture is, in short, the aggregate of people's beliefs, values, customs and norms to the extent that it regulates their behaviour in an organization: to paraphrase Bob Diamond ${ }^{9}$, it is how you behave when no-one is looking.

This raises questions about what kind of culture enhances/promotes sustainability in a university. This can be conceived as one in which members and stakeholders hold in common a set of assumptions, beliefs and values and behave in a way reflecting a commitment to operate in a manner consistent with the sustainability principles of balancing economic efficiency, social equity and environmental accountability (after Bertels, Papania, and Papania 2010; Bartell 2003): sustainability culture is based upon the supportive integration of the organization's mission, values, goals and strategy (Galpin, Whitttington, Bell et al., 2015) and expressed in more or less visible ways, it promotes the values of sustainability such as openness and transparency.

Consequently, organizations not built with sustainability values can transform their core ideology and change their organizational culture over time through the manipulation of cultural artefacts so as to incorporate sustainability into the company ethos (Crittenden et al., 2011).

\footnotetext{
${ }^{9}$ Former Chief Executive of Barclays, see http://news.bbc.co.uk/today/hi/today/newsid 9630000/9630673.stm, accessed July 14, 2015
} 
Based on the previous developing a sustainability culture can be conceived as a process of organizational change...

- ... requiring change in culture across diverse groups...

- ... composed of visible and invisible elements...

- ...in which the visible elements are manageable and accessible via quantitative research methods...

- ...and invisible elements less amenable to management intervention, change slowly over time in response to changes at the visible level and observable only through rich insights derived from a qualitative approach (see figure 1).

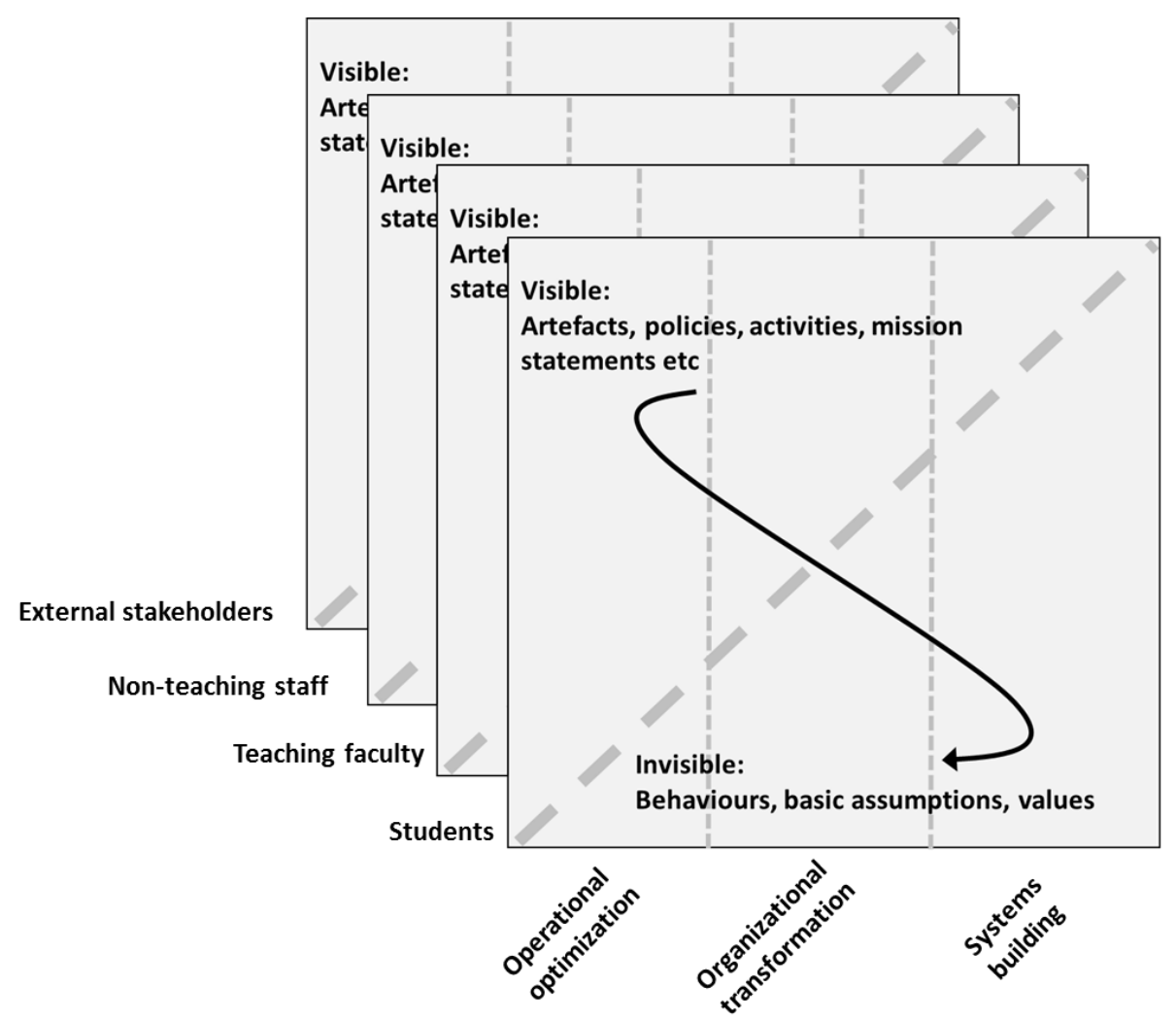

Figure 1: Sustainability culture conceptual framework

\section{APPLYING THE FRAMEWORK: THE CASE OF UNIVERSITY OF WORCESTER}

The University of Worcester (UW) is ambitious to foster a culture that values sustainability and has a long-standing commitment to act in a sustainable and environmentally responsible manner. Its first Sustainability Policy was adopted in 2007, is reviewed annually and remains a core value, 'promoting the principles of sustainability through teaching, research and knowledge exchange activities...and to promote sustainable communities, services and businesses and foster a culture that values sustainability in arts and culture, and to promote social enterprise in the region' (UW, 2016).

UW's sustainability strategy currently identifies 12 key areas of policy comprising of initiatives ranging from the technical to the behavioural and designed either to mitigate negative impacts or provide positive programmes to impact various stakeholder communities (see Box 2). 


\section{Biodiversity:}

Enhance biodiversity and incorporate biodiversity in environmental management, creating new opportunities for wildlife on campus wherever possible

\section{Community involvement:}

Promote communication with internal and external interested parties and respond appropriately to reasonable requests for information about our environmental performance

\section{Construction \& refurbishment:}

Ensure sustainable approaches in all construction and refurbishment and incorporate energy efficient approaches in all work

\section{Education for sustainability:}

Embed inclusion of sustainability principles in the curriculum and support research in relevant areas

\section{Prevent pollution:}

By reducing emissions and discharges and regularly reviewing practice against benchmarks

Reduce energy use:

Recognise the potential impact of climate change and the strategic and operational need to control, manage and reduce carbon dioxide and other greenhouse gas emissions; Comply with all relevant environmental legislation, regulations and requirement

Food:

We recognise that it is our responsibility to encourage our suppliers and contractors to minimise negative environmental and social effects associated with the products and services they provide. We will also strive to ensure that local and smaller suppliers are not discriminated against in the procurement process and specifications, within the parameters of our overall purchasing strategy.

\section{Health \& wellbeing:}

Provide appropriate environmental training for all our staff and students and encourage them to support the EMS Incorporate environmental responsibility in all staff job descriptions

\section{Procurement:}

Encourage environmentally responsible procurement and employ whole-life costing and environmental performance criteria for selection

Transport (incl. Transport-fleet and business travel):

Encourage environmentally-friendly transport and implement a Sustainable Transport/Green Travel Plan

\section{Waste management:}

Re-use resources whenever possible rather than dispose of them; Encourage the use of recycled materials and recycling initiatives; Comply with all relevant environmental legislation, regulations and requirements

Water:

Reduce our use of water

UW has made progress in delivering on this agenda, implementing a wide range of sustainabilityrelated initiatives against these strategic areas, some of which are mapped against the culture framework in appendix. As a result, the university has risen from 93rd in the People and Planet League 2007 to top 5 by $2016^{10}$. Specific examples of UW's sustainability initiatives include; ongoing investment in retrofit LED lighting; implementing all the recommendations from a water audit such as changing toilets to low flush and installing reduced flow rate showers in halls of residence;

\footnotetext{
${ }^{10}$ See https://peopleandplanet.org/university-league
} 
pursuing external validation and certification, in May 2010 UW became the first in England to achieve the EcoCampus Platinum Award for the whole campus; the launch of New Midlands Sustainability Network at the University of Worcester to leverage local network effects; Student Ambassadors, role models trained by the University's Communications team to support a variety of on and off campus activities; and, the ongoing Energise Worcester project in which students are trained as advocates for adopting pro-environmental behaviour in off-campus accommodation through the cascading effects of peer-to-peer support (Jacobs 2002).

Consequently, there is significant empirical evidence (see also appendix) of UW having and continuing to introduce operational and technical initiatives in support of sustainability. For several years, UW has been surveying student and staff awareness and attitudes to its sustainability policy and diverse initiatives. Figure 2 presents the percentage of staff and student respondents fully aware of the university's sustainability initiatives, and is aggregated from responses to items relating to 10 separate initiatives ${ }^{11}$.The data illustrate that only approximately half the staff and one-quarter of the student population report being fully aware.

In a recent evaluation of UW's participation in the Green Academy organizational change programme (launched in 2011 by the UK's Higher Education Academy), it was recommended that UW "needed to take a more radical and holistic institutional approach" (McCoshan and Martin 2012, 26). The question posed is 'where next?': how can the progress achieved thus far be maintained and more deeply embedded in the DNA of the university?

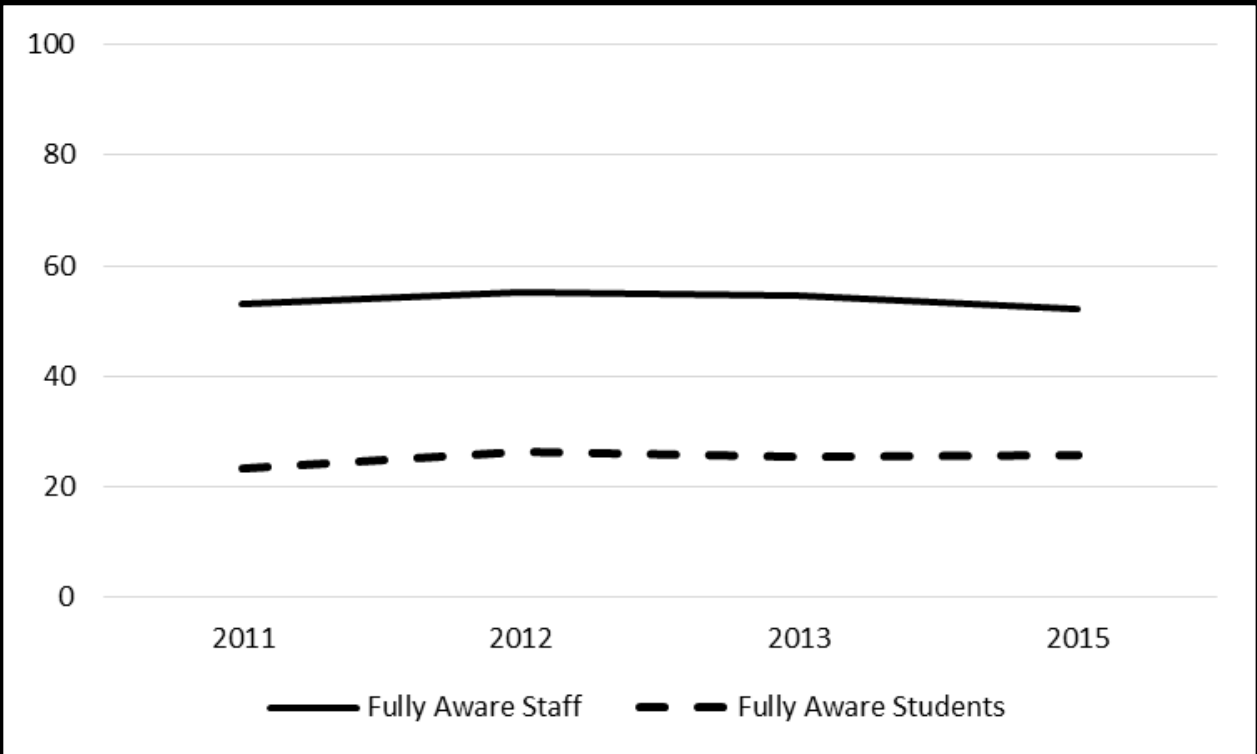

\section{Figure 2: Faculty and student awareness of sustainability initiatives at University of Worcester}

Figure 2 therefore raises two important questions. First, what accounts for the gap between student and staff levels of awareness (approximately $25 \%$ versus approximately $53 \%$, respectively)? Second, why, despite activity levels and the range of initiatives do these values remain stubbornly static over the period? That is, if, as has been argued earlier, culture is 'the way we do things round here', do these data indicate that a sustainability culture at UW remains yet to be embedded?

These survey data suggest that significant challenges remain in developing a sustainability culture at UW, but how typical is UW's experience? At the University of Michigan (UoM), Marans, Callewaert,

\footnotetext{
${ }^{11}$ Note: The survey was not run in 2014
} 
and Shriberg (2015) have reported successfully making operational and technical changes but similarly failing to embed a culture of sustainability.

Since 2012 the UoM has been monitoring student, staff \& faculty awareness of that university's efforts around key sustainability initiatives (climate action, waste reduction and healthy environments). Although not yet directly comparable, the respective surveys of UW and UoM are becoming increasingly aligned. For example, through a Fulbright exchange program UW and the UoM are collaborating on programmes for assessing campus sustainability cultural information. Figure 3 presents standardised data relating to items investigating awareness and behaviour at UoM, presented on a 0 to 10 scale (Marans, Callewaert and Webster, 2016).

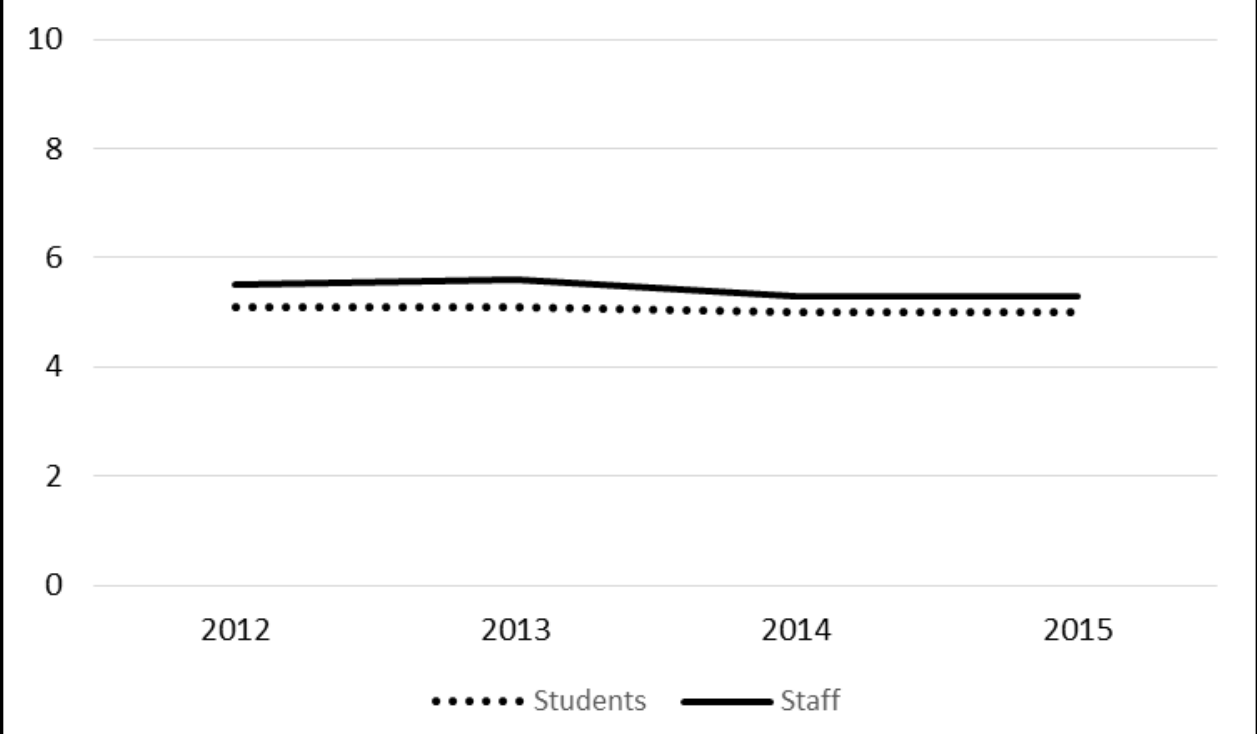

Figure 3: Staff and student behaviours and awareness of sustainability initiatives at University of Michigan (Source: Professor RW Marans, with permission)

Unlike in the case of UW, awareness and behaviour of students and staff at UoM display broadly equivalent levels but, as in the case of UW, stubbornly remain unimproved over time.

\section{DISCUSSION}

A sustainable university requires individuals who behave sustainably: autonomous, self-regulating and responsible. It is a place where behaviours (as expressed in the university's vision) are regarded amongst all stakeholders as desirable qualities and are promoted as such (after Du Gay and Salaman, 1992). Paraphrasing Peters and Waterman (1982), if an organization has an appropriate culture of sustainability, its members and stakeholders will adopt a sustainable relation to self and these will translate to the organizational level.

As discussed, the notion of organizational culture implies a set of shared goals and values held in common by organizational members which inspire and motivate consistent behaviours. Policies and initiatives have expressive significance: they help define desired modes of behaviour. The question remains as to the extent to which these have been inculcated as shared norms at UW, reflective of a set of community shared values. The truth is that there is a dynamic process at play in which values (read culture) and expressive functions such as policies and initiatives shape and are shaped by each other. Evidently, there is great commitment to the sustainability journey from a number of students and staff at UW and the university's existing sustainability culture is rooted in these tangible, 'expressive functions'. 
However, students' low and staff members' stubbornly persistent levels of awareness suggests a Organizations (e.g. nuclear power stations, air traffic control and submarines that are oriented toward averting disaster) have embedded powerful processes of enculturation that emphasise the high reliability outcome (Weick, 1987). But universities are a particular case, characterised by transient populations of students some (many?) of whom joining as freshmen may be, due to previous life experiences, unfamiliar with the desired behaviours. Is it the case that students arrive at UW lacking a general awareness of sustainability issues, and so require bringing up to speed? Or, do they arrive 'sustainability literate' but fail for some reason(s) to become fully engaged with UW practice?

Shedding some light on this question are reviews of UW's students' attitudes toward and behaviour relating to the use of smart energy metering. Braconnier, Goddard, Puckett et al. (2016) and Healy, Libby, Sudol et al. (2017) note a gap between attitude and behaviour: students endorse the idea of smart meter use to manage and conserve energy, but frequently fail to convert attitude into action.

The idea that people's behaviours do not always align with their professed attitudes is not new: this is the difference between theory in use and espoused theory (Argyris and Schön, 1978). The latter refers to the cognitive models that people suggest underpin their behaviours, but frequently, and manifestly, a gap between attitude and behaviour is apparent.

This distinction resonates with Schein's decomposition of culture into artefacts, espoused values and, assumptions: or, as is framed in the proposed conceptualisation, the visible and invisible. Previous research on these mental models has argued that change fails to occur because the target is in "conflict with deeply held internal images of how the world works" (Senge, 1992: 5). But, in the case of UW's sustainability initiatives there would appear to be consonance between most people's espoused theories and desired behaviours and practices: yet still they remain hard to reach.

Solutions to this paradox require more work: one reason may be that the desired behaviours remain too difficult for people to enact, that there are infrastructural or image or cost or other factors that prevent them from being realised. As Healy et al's (2017) evaluation concluded, there are potentially three complicating factors hindering the uptake of smart heating controls: insufficient levels of student motivation to improve energy efficiency, the apparent absence of fuel poverty in the population studied, and concerns regarding privacy.

The evidence of UW's and UoM's surveys suggests that, as others have found (e.g. Dlouhá, Glavič, and Barton (2017)), progress toward establishing a sustainability culture remains sluggish. But, this is the nature of culture change, and the challenge remains of having a clear conceptualisation of what a culture for sustainability in the university sector actually means, how to implement one and how to monitor its development (Verhulst and Lambrechts 2014). Adopting a cultural framework approach will prove helpful for researchers and stakeholders to move beyond a piecemeal and technicallyoriented approach to the challenge of university sustainability.

Tierney (1988) was amongst the first to apply the notion of culture to the university sector and outlines a set of essential concepts that would constitute a framework of organizational culture in a university: environment, mission, socialisation, information, strategy and, leadership. Since then, culture has been operationalised in a range of aspects of university activity such as, for example, management approaches (Sporn 1996), leadership (Asmawi, Zakaria, and Wei 2013) and internationalisation (Bartell 2003). The concept has, too, been applied to provide insight into the sustainability journeys of universities (Disterheft, Caeiro, Azeiteiro et al., 2015; Ferrer-Balas, Buckland \& de Mingo 2009; Isaksson, Johnson \& Garvare 2013; Lozano 2006).

Consequently, the proposed framework joins an existing collection designed to enable the implementation of university sustainability as well as to monitor and evaluate progress. It is though, to the best of the authors' knowledge, the only one that explicitly integrates contemporary thinking 
on the systemic dimension of sustainability with important factors drawn from cultural change theory. For example, The Association for the Advancement of Sustainability in Higher Education's Sustainability Tracking, Assessment \& Rating System (STARS ${ }^{\mathrm{TM}}$ ) is a benchmarking tool designed to enable colleges and universities to gauge their progress toward sustainability (AASHE 2014), but fails explicitly to address the question of culture. The Assessment Instrument for Sustainability in Higher Education (AISHE) (Roorda, Rammel, Waara et al., 2009) shares similar ambitions, but again fails to provide any mechanism directly to map the development of a culture for sustainability. Previously, Shriberg (2002) reviewed 11 such instruments and frameworks, and concluded them to be limited to operational eco-efficiency, tending to measure "what" campuses are doing and "how" they are doing it. The "why", the motivational cultural aspects which are frequently a neglected dimension (Boyko, Gaterell, Barber et al., 2012), is captured in the proposed approach.

Consequently, one contribution is in providing a conceptualisation of university sustainability culture that integrates findings from both the sustainability and cultural change literatures and describes in more fine-grained detail than previously, more aspects of the transformation journey. The benefits of the conceptual framework reside in helping researchers and stakeholders move beyond the technical and piecemeal approaches that have been identified as limitations of previous efforts.

Cultural change will be reflected in and triggered by changes in individual behaviour. To continue to promote this, sustainability and the university's incentivisation and reward systems should be closely aligned (Freeland, 1992): in their absence, existing configurations can act as a barrier (Trencher et al., 2014). If the desired behaviours are not incentivised they are likely not to be realised: if they are mandated by bureaucracy or regulation, only the minimal performance levels are likely to be realised (Du Gay and Salaman, 1992). If members are coerced to implement practices with a low cultural fit this can result in the mutual adaptation of the practices and organizational culture, possibly diluting the impact of either or both (Canato, Ravasi \& Phillips, 2013).

Such prescriptions direct attention toward the less quantifiable indicators of cultural change, and more subjectively understood, like emotional, psychological, and social transformations. The progress of change can be assessed through changes in individual's behaviour, stakeholder feedback and, in the tangible and intangible artefacts of culture through which and in which the desired sustainability ends are expressed, delineated, normalised and instrumentalised (Du Gay and Salaman, 1992). In 2012, for example, UW opened the first joint public and university library in Europe. It is an exemplar of systemic reach in cultural transformation because of its outstanding environmental performance and for its social engagement with the wider local community and community groups. Evaluating the impact of such initiatives requires the investigator tries to become a "native" (Cameron and Quinn 2011) and collect data through observation of and participation in cultural and social processes, as well as in-depth interviews (Schensul 2009).

\section{CONCLUSION}

This study expands the boundaries of research in the field of organizational transformations toward sustainability in the context of HEls. The article brings together the literature on journeys to sustainability with organizational culture scholarship to propose and apply a conceptual framework to inform the design, implementation and monitoring of initiatives to accelerate embedding cultures for sustainability. Consequently, the article's main contribution is a cognitive framework to support managing the process of organizational change toward sustainability whose application is illustrated with empirical instances drawn from the case of University of Worcester. As such, this work will have implications of significance to university faculty, managers, students and wider stakeholder groups as well as scholars invested in the sustainability agenda.

This article has argued that an organizational culture of sustainability develops over time because of actions applied in the 'visible' layer and is likely manifest in different forms within sub-cultures. It is further argued that to fully understand an organizational culture a mixed-methods research 
approach is required that combines quantitative elements to access its visible artefacts and a qualitative approach to unearth and track change in the underpinning basic assumptions and values.

As noted in the UN's recent Shaping the future we want report, the tendency to date has been to measure inputs such as technologies, changes in curricula and policy into the sustainable transformation process. It has been difficult to assess whether or not these have led to significant attainments in learning or behaviour change within institutions, communities or at the macro level. The concept of culture provides a lens through which this knowledge gap can be explored. The conceptual framework outlined here is a step towards progress in this direction. It remains a workin-progress with much still to be done. The process and progress of this initiative will be closely monitored with findings contributing to the development of further in-depth cases of transformation to HEI Sustainability as well as to developing better understanding of how organizational cultures and climates are shaped and reshaped as members of the organization address sustainability issues.

Making culture visible in this way can help universities achieve their sustainability ambitions and to narrow the gap between publicly espoused values and organizational behaviour and so improve their social legitimacy.

\section{ACKNOWLEDGEMENTS}

This research did not receive any specific grant from funding agencies in the public, commercial, or not-for-profit sectors.

The authors gratefully acknowledge permission from Professor RW Marans to present the data in Figure 3 and the data analysis assistance of Mihaela Getzova.

The authors would also like to acknowledge the helpful contributions through their comments, insight and feedback, of the reviewers for the Journal of Cleaner Production as well as subject editor Dr. Sandra Caeiro.

\section{APPENDIX: UNIVERSITY OF WORCESTER SUSTAINABILITY POLICY AREAS, ILLUSTRATIVE INITIATIVES AND METRICS. SOURCE: UW (2016), BOOM (2017).}

\begin{tabular}{|ll|}
\hline Biodiversity \\
\hline Indicative activities and initiatives & Indicative measures (not exhaustive) \\
\hline Operational optimization & \\
" Collaborate with Nature Society; " & \\
Malvern Meadow - native wildflower & "Map St John's Campus in detail for land use by August \\
planting; » University allotment on & 2017 \\
campus & "Implement all detailed actions as set out in the \\
Organizational transformation & Biodiversity Action plan \\
n/a & \\
Systems building & \\
n/a & \\
\hline
\end{tabular}

\section{Community involvement}

Indicative activities and initiatives

Indicative measures (not exhaustive) 


\section{Operational optimization \\ » Wychavon Intelligently Green Awards - for school children}

\section{Organizational transformation}

" Susthingsout.com and front facing website

\section{Systems building}

"Go Green Week in the Community; " Energize Worcester; " Skills for Tomorrow - local business involvement; " Midlands Sustainable Further and Higher Education Network - Emerging Leaders programme
"Increase student sign-up to participation in SSO by $10 \%$ on $2011 / 12$ levels

» Work closely with and support student groups such as People and Planet, Nature Society to raise awareness on environmental issues

" To use press evaluation and Google analytics to measure awareness of the University's sustainability drive in the local community and within the higher education sector. To inform possible target setting for community awareness

» Promote collaborative working within UW and with Worcestershire and Worcester City Council and other 3rd sector organizations.

\section{Construction \& refurbishment}

Indicative activities and initiatives

Operational optimization

» Implementing new refurbishment sustainability standard SKA for Art House Refurbishment, going for Higher Standard - Gold

\section{Organizational transformation} $\mathrm{n} / \mathrm{a}$

\section{Systems building} $\mathrm{n} / \mathrm{a}$
Indicative measures (not exhaustive)

" All new build projects should be designed to achieve a DEC $B$ rating or above

» Ensure the 'Halving Waste to Landfill' clauses is included in all building and refurbishment contracts for consultants and contractor

" BREEAM assessment to be carried out on all new buildings of over $1000 \mathrm{~m} 2$ with a target to achieve a rating of 'Excellent' but with a minimum rating of 'Very Good' in cases where there are good and explicit reasons why an excellent rating could not be achieved 


\begin{tabular}{|ll|}
\hline Education for sustainability \\
\hline Indicative activities and initiatives & Indicative measures (not exhaustive) \\
\hline Operational optimization & \\
" Collaborate with Nature Society; & \\
Malvern Meadow - native wildflower & \\
planting; " University allotment on & " Retain Responsible Futures accreditation, and \\
campus & increase score from 234 to 250 at next reaccreditation \\
Organizational transformation & " Monitor, evaluate and disseminate the impact of \\
" Go Green Week and sustainability & innovative teaching model for the electives, to inform \\
elective; " Learning for Sustainable & new electives/degrees for 2017 \\
Futures & \\
Systems building & \\
"Skills for Tomorrow; " Susthingsout.com & \\
\hline
\end{tabular}

\begin{tabular}{|ll|}
\hline Prevent pollution & \\
\hline Indicative activities and initiatives & Indicative measures (not exhaustive) \\
\hline Operational optimization & \\
" Emergency Hazardous Materials Spill & \\
drill; " Development of in-house training & " Reduce fugitive F Gas emission by 25\% annually from \\
materials & a baseline 2013-14 of 18.25t CO2e \\
Organizational transformation & " Do additional promotion of pollution awareness- \\
n/a & raising and with new facilities staff by May 2016 \\
Systems building & \\
n/a & \\
\hline
\end{tabular}

\begin{tabular}{|cl|}
\hline Reduce energy use & \\
\hline Indicative activities and initiatives & Indicative measures (not exhaustive) \\
\hline Operational optimization & \\
Energy Management Student Placement - & " $5 \%$ p.a. reduction GHGe emissions in energy against a \\
comparing and contrasting University data & $2008 / 9$ baseline from 2010 to 2020. \\
with other Universities & Consumption targets \\
Organizational transformation & " $6 \%$ reduction in kWh gas consumption from 2015- \\
"Student Switch Off; "Green Impact & 2016 \\
Systems building & " Increase renewable energy generation to 2\% of total \\
Energize Worcester: http://energize- & consumption by 2020 \\
worcester.co.uk/ & significant buildings to improve the DEC to target levels. \\
\hline
\end{tabular}




\begin{tabular}{|cl|}
\hline Food & \\
\hline Indicative activities and initiatives & Indicative measures (not exhaustive) \\
\hline Operational optimization & \\
" Fair Trade; " Drinking Water fountain & " Obtain Sustainable Restaurant Association \\
map of campus; » University allotment & certification \\
Organizational transformation & " Minimise food waste and comply with the \\
" Green Impact; " On campus open pizza & $\begin{array}{l}\text { University's separate food waste collection service and } \\
\text { provide facilities for recycling and disposing of plate }\end{array}$ \\
oven for student and community use & $\begin{array}{l}\text { waste } \\
\text { Systems building }\end{array}$ \\
" Go Green Week - food day & "Promote part-time Carnivore campaigns \\
\hline
\end{tabular}

\begin{tabular}{|ll|}
\hline Health \& wellbeing \\
\hline Indicative activities and initiatives & Indicative measures (not exhaustive) \\
\hline Operational optimization & \\
" Every other one - water; " University & " Achieve level 3 standard by August 2017 \\
Mile & " A full set of qualitative targets with completion dates \\
Organizational transformation & have been agreed for H\&W by signing up to the \\
" Fit-4-Life; " Green Impact & Worcestershire Works Well framework. \\
Systems building & \\
n/a
\end{tabular}

\begin{tabular}{|ll|}
\hline Procurement & \\
\hline Indicative activities and initiatives & Indicative measures (not exhaustive) \\
\hline Operational optimization & \\
" Supplier Engagement days; " & \\
Engagement of Management Students in & \\
ethical procurement practices and & " Reduce the carbon emissions attributed to contracts \\
workers' rights workshops & the University is able to influence by 5\% from 2011-12 \\
Organizational transformation & baseline by 2018 \\
n/a & " Implement Net Positive tool kit for supplier reporting \\
Systems building & \\
n/a
\end{tabular}


Transport (incl. Transport-fleet and business travel)

\begin{tabular}{|cl|}
\hline Indicative activities and initiatives & Indicative measures (not exhaustive) \\
\hline Operational optimization & " $25 \%$ reduction absolute tCO2e emissions from staff \\
" Bike Loan Scheme; " Car share; " Cycle & and students' commuting to University on a daily basis \\
to work; " Subsidised Bus Tickets & by 2020 from a baseline $2010 / 11$ of 6,843 tCO2e \\
Organizational transformation & " $5 \%$ reduction in the tC02e emissions from travel \\
" Testing innovative bike stack racks to & between students' homes and the University by 2018 \\
introduce for staff & from a baseline $2010 / 11$ of 2,891 tCO2e \\
Systems building & " $20 \%$ reduction in the percentage of staff travelling by \\
n/a & car alone to work by 2018 - i.e. a reduction from $55 \%$ in \\
& " Develop department pool bike pilot scheme, whereby \\
& departments have access to a bikes for intersite travel.
\end{tabular}

\begin{tabular}{|cl|}
\hline Waste management & \\
\hline Indicative activities and initiatives & Indicative measures (not exhaustive) \\
\hline Operational optimization & " Reduce waste collection weight by 3\% per annum \\
" Student led food bank collections - end & from baseline 2015-6 from 2017-2020. \\
of semester; " BHF collections on move & " Further promote local re-use services, such as Repair \\
out & Café, BorroClub and groups to the university \\
Organizational transformation & community \\
» White Bags project with City Council & " Implement pilot Green Impact Excellence project with \\
office cleaning staff; to increase office recycling rates \\
Systems building & amongst staff and increase education and \\
n/a & understanding amongst cleaners. Extend across campus \\
\end{tabular}

\begin{tabular}{|ll|}
\hline Water & \\
\hline Indicative activities and initiatives & Indicative measures (not exhaustive) \\
\hline Operational optimization & " 2.5\% p.a. reduction in water GHGe emissions from \\
In discussion with Neopearl to introduce & consumption against a 2012-13 baseline from 2014 to \\
retro fit flow rate adaptors for staff and & 2019 \\
student use. & " All rain water harvesting installed on halls of \\
Organizational transformation & residence to be fully functional and recorded by March \\
n/a & 2017 \\
Systems building & " Main meters to be fully functional on pulsed outputs \\
n/a & and recorded on a M\&T. Enable a M\&T system to \\
& establish a water leak detection programme by July \\
\hline
\end{tabular}




\section{REFERENCES}

AASHE, 2014. STARS Technical manual: version 2.0. Association for the Advancement of Sustainability in Higher Education.

Adams, R.J., Jeanrenaud, S., Bessant, J., Denyer, D., Overy, P., 2016. Sustainability-oriented innovation: a systematic review. International Journal of Management Reviews 18(2), 180-205.

Alshuwaikhat, H.M., Abubakar, I., 2008. An integrated approach to achieving campus sustainability: assessment of the current campus environmental management practices. Journal of Cleaner Production 16(16), 1777-1785.

Arbo, P., Benneworth, P., 2007. Understanding the regional contribution of higher education institutions: Understanding the regional contribution of higher education institutions: $A$ literature review. OECD/IMHE.

Armenakis, A., Brown, S., Mehta, A., 2011. Organizational Culture: Assessment and Transformation. Journal of Change Management 11(3), 305-328.

Asmawi, A., Zakaria, S., Wei, C.C., 2013. Understanding transformational leadership and R\&D culture in Malaysian universities. Innovation: Management, Policy \& Practice 15(3), 287-304.

Bansal, P., Bertels, S., Ewart, T., MacConnachie, P., O'Brien, J., 2012. Bridging the Research-Practice Gap. Academy of Management Perspectives 26(1), 73-92.

Bartell, M., 2003. Internationalization of universities: A university culture-based framework. Higher Education 45(1), 43-70.

Barth, M., Michelsen, G., Rieckmann, M., Thomas, I., 2016. Routledge handbook of sustainable development in higher education. Routledge, Abingdon \& New York.

Becher, T., Trowler, P., 2001. Academic tribes and territories: Intellectual enquiry and the culture of disciplines. McGraw-Hill Education (UK).

Bertels, S., Papania, L., Papania, D., 2010. Embedding sustainability in organizational culture. A systematic review of the body of knowledge. Network for Business Sustainability.

Beusch, P., 2014. Towards sustainable capitalism in the development of higher education business school curricula and management. International Journal of Educational Management 28(5), 523-545.

Bocken, N.M.P., Short, S.W., Rana, P., Evans, S., 2014. A literature and practice review to develop sustainable business model archetypes. Journal of Cleaner Production 65(0), 42-56.

Bone, E., Agombar, J., 2011. First-year attitudes towards, and skills in, sustainable development. Higher Education Academy/National Union of Students.

Boom, K. (2017). University of Worcester Sustainability Strategy 2018-2025 (available https://www.worcester.ac.uk/ 2018)

Boyko, C.T., Gaterell, M.R., Barber, A.R., Brown, J., Bryson, J.R., Butler, D., Caputo, S., Caserio, M., Coles, R., Cooper, R., 2012. Benchmarking sustainability in cities: The role of indicators and future scenarios. Global Environmental Change 22(1), 245-254.

Braconnier, D., Goddard, K., Puckett, S., Ruiz-Cadalso, D., 2016. Energize Worcester phase II. Analysis of consumer energy behavior in homes of multiple occupancy near the University of Worcester. Worcester Polytechnic Institute, Massachusetts. 
Brennan, J., King, R., Lebeau, Y., 2004. The role of universities in the transformation of societies. Synthesis Report. Centre for Higher Education Research and Information/Association of Commonwealth Universities, UK.

Brinkhurst, M., Rose, P., Maurice, G., Ackerman, J.D., 2011. Achieving campus sustainability: topdown, bottom-up, or neither? International Journal of Sustainability in Higher Education 12(4), 338-354.

Butt, L., More, E., Avery, G.C., 2014. The myth of the 'green student': student involvement in Australian university sustainability programmes. Studies in Higher Education 39(5), 786-804.

Cameron, K.S., Quinn, R.E., 2011. Diagnosing and changing organizational culture: Based on the competing values framework. John Wiley \& Sons.

Canato, A., Ravasi, D., Phillips, N., 2013. Coerced practice implementation in cases of low cultural fit: Cultural change and practice adaptation during the implementation of Six Sigma at 3M. Academy of Management Journal 56(6), 1724-1753.

Carson, R., 1962. Silent spring. Houghton Mifflin.

Churchman, C.W., 1967. Guest editorial: Wicked problems. Management Science 14(4), B141-B142.

Clark, B.R., 1983. The Higher Education System: Academic Organization in Cross-National Perspective. University of California Press, Berkeley.

Cohen, M.D., March, J.G., Olsen, J.P., 1972. A garbage can model of organizational choice. Administrative Science Quarterly 17(1), 1-25.

Cooke, R.A., Szumal, J.L., 1993. Measuring normative beliefs and shared behavioral expectations in organizations: The reliability and validity of the Organizational Culture Inventory. Psychological Reports 72(3c), 1299-1330.

Corcoran, P.B., Weakland, J.P., Wals, A.E., 2017. Envisioning futures for environmental and sustainability education. Wageningen Academic Publishers.

Costanza, R., d'Arge, R., de Groot, R., Farber, S., Grasso, M., Hannon, B., Limburg, K., Naeem, S., O'Neill, R.V., Paruelo, J., Raskin, R.G., Sutton, P., van den Belt, M., 1997. The value of the world's ecosystem services and natural capital. Nature 387(6630), 253-260.

Cotton, D.R.E., Alcock, I., 2013. Commitment to environmental sustainability in the UK student population. Studies in Higher Education 38(10), 1457-1471.

Crittenden, V., Crittenden, W., Ferrell, L., Ferrell, O., Pinney, C., 2011. Market-oriented sustainability: a conceptual framework and propositions. Journal of the Academy of Marketing Science 39(1), 71-85.

Diamond, J., 2005. Collapse: How societies choose to fail or succeed. Viking, London.

Dill, D.D., 2012. The management of academic culture revisited: integrating universities in an entrepreneurial age. Managing Reform in Universities: The Dynamics of Culture, Identity and Organisational Change 222.

Disterheft, A., Caeiro, S., Azeiteiro, U.M., Filho, W.L., 2015. Sustainable universities - a study of critical success factors for participatory approaches. Journal of Cleaner Production 106, 11-21.

Dlouhá, J., Glavič, P., Barton, A., 2017. Higher education in Central European countries - Critical factors for sustainability transition. Journal of Cleaner Production 151,670-684.

Du Gay, P., Salaman, G., 1992. The cult [ure] of the customer. Journal of Management Studies 29(5), 615-633.

Elkington, J., 1997. Cannibals with forks. Capstone, Oxford (UK). 
Epstein, M.J., Roy, M., 2001. Sustainability in action: Identifying and measuring the key performance drivers. Long Range Planning 34(5), 585-604.

Ferrer-Balas, D., Buckland, H., de Mingo, M., 2009. Explorations on the University's role in society for sustainable development through a systems transition approach. Case-study of the Technical University of Catalonia (UPC). Journal of Cleaner Production 17(12), 1075-1085.

Finlay, J., Massey, J., 2012. Eco-campus: applying the ecocity model to develop green university and college campuses. International Journal of Sustainability in Higher Education 13(2), 150-165.

Freeland, R.M., 1992. Academia's golden age: Universities in Massachusetts, 1945-1970. Oxford University Press on Demand.

Galpin, T., Whitttington, J.L., Bell, G., Kakabadse, N., Fleur, M., 2015. Is your sustainability strategy sustainable? Creating a culture of sustainability. Corporate Governance: The International Journal of Business in Society 15(1).

Geertz, C., 1973. Thick description: Toward in interpretive theory of culture, The interpretation of cultures: Selected essays. Basic Books, New York, pp. 3-30.

Hamann, R., April, K., 2013. On the role and capabilities of collaborative intermediary organisations in urban sustainability transitions. Journal of Cleaner Production 50, 12-21.

Healy, B., Libby, A., Sudol, R., White, C., 2017. EnergizeWorcester: Smart Heating Controls in Student HMOs, An Interactive Qualifying Project Submitted to the Faculty of Worcester Polytechnic Institute, in partial fulfillment of the requirements for the Degree of Bachelor of Science. Worcester Polytechnic Institute, http://wp.wpi.edu/london/projects/2015-projectssummer/energize-worcester/ [accessed July 2017].

Hoover, E., Harder, M.K., 2014. What lies beneath the surface? The hidden complexities of organizational change for sustainability in higher education. Journal of Cleaner Production.

Hunt, C.B., Auster, E.R., 1990. Proactive environmental management: avoiding the toxic trap. Sloan Management Review 31(2), 7-18.

Ingham, B., 2006. CSR: The wolf in sheep's clothing, Journal of Public Affairs. John Wiley \& Sons, Inc., pp. 283-285.

Isaksson, R., Johnson, M.W., Garvare, R., 2013. Towards a Model for Measuring University Sustainability. Proceedings of the International Conference on Intellectual Capital, Knowledge Management \& Organizational Learning, 213-221.

ISCN Secretariat, 2014. Best Practice in Campus Sustainability - Latest Examples from ISCN and GULF Schools. International Sustainable Campus Network (ISCN), Boston, MA.

Jacobs, G., van Witteloostuijn, A., Christe-Zeyse, J., 2013. A theoretical framework of organizational change. Journal of Organizational Change Management 26(5), 772-792.

Jacobs, R.L., 2002. Institutionalizing organizational change through cascade training. Journal of European Industrial Training 26(2/3/4), 177-182.

Kagan, S., 2014. Art and Sustainability: Connecting Patterns for a Culture of Complexity (2nd emended edition 2013). transcript Verlag.

Kaplowitz, M.D., Yeboah, F.K., Thorp, L., Wilson, A.M., 2009. Garnering input for recycling communication strategies at a Big Ten University. Resources, Conservation and Recycling 53(11), 612-623.

Kolk, A., Mauser, A., 2002. The evolution of environmental management: from stage models to performance evaluation. Business Strategy and the Environment 11(1), 14-31. 
Kotter, J.P., Heskett, J.L., 2011. Corporate culture and performance. Free Press.

Kwan, P., Walker, A., 2004. Validating the competing values model as a representation of organizational culture through inter-institutional comparisons. Organizational Analysis 12(1), 21-37.

Lamming, R., Faruk, A., Cousins, P., 1999. Environmental soundness: a pragmatic alternative to expectations of sustainable development in business strategy. Business Strategy \& the Environment 8(3), 177-188.

Levy, B.L.M., Marans, R.W., 2012. Towards a campus culture of environmental sustainability. International Journal of Sustainability in Higher Education 13(4), 365-377.

Linnenluecke, M.K., Griffiths, A., 2010. Corporate sustainability and organizational culture. Journal of World Business 45(4), 357-366.

Linnenluecke, M.K., Russell, S.V., Griffiths, A., 2009. Subcultures and sustainability practices: The impact on understanding corporate sustainability. Business Strategy and the Environment 18(7), 432-452.

Lozano, R., 2006. Incorporation and institutionalization of SD into universities: breaking through barriers to change. Journal of Cleaner Production 14(9), 787-796.

Lozano, R., Lukman, R., Lozano, F.J., Huisingh, D., Lambrechts, W., 2013. Declarations for sustainability in higher education: becoming better leaders, through addressing the university system. Journal of Cleaner Production 48(0), 10-19.

Lukman, R., Glavič, P., 2007. What are the key elements of a sustainable university? Clean Technologies and Environmental Policy 9(2), 103-114.

Luna, H., Maxey, L., 2013. Towards a green academy, in: Sterling, S., Maxey, L., Luna, H. (Eds.), The sustainable university: Progress and prospects. Earthscan from Routledge, Oxon, pp. 281-303.

Marans, R., Callewaert, J., Webster, N., 2016. Sustainability cultural indicators program: fourth year report. Monitoring the culture of sustainability at the university of Michigan: Fall 2015. Graham Sustainability Institute, University of Michigan, http://graham.umich.edu/campus/scip [accessed Feb 2017].

Marans, R.W., Callewaert, J., Shriberg, M., 2015. Enhancing and monitoring sustainability culture at the University of Michigan, Transformative Approaches to Sustainable Development at Universities. Springer, pp. 165-179.

Martin, J., 2015. Organizational Culture, Wiley Encyclopedia of Management. John Wiley \& Sons, Ltd.

Martin, J., Frost, P.J., O’Neill, O.A., 2006. Organizational culture: Beyond struggles for intellectual dominance, in: Clegg, S., Hardy, C., Nord, W.R., Lawrence, T. (Eds.), The Handbook of Organization Studies. Sage Publications, London, pp. 725-753.

Martin, S., Dillon, J., Higgins, P., Peters, C., Scott, W., 2013. Divergent evolution in education for sustainable development policy in the United Kingdom: Current status, best practice, and opportunities for the future. Sustainability 5(4), 1522-1544.

Martin, S., McCoshan, A., McEwen, L., 2014. Embedding sustainability into the higher education curriculum: Lessons from the UK's Green Academy Change Programme, The 4th World Sustainability Forum 2014. http://www.sciforum.net/conference/wsf-4 [accessed May 2016].

Martin, S., Murray, P., 2011. The role of wicked problems: Values in personal and organisational change. Learning and Teaching in Higher Education (LATHE) 5, 163-169.

McCoshan, A., Martin, S., 2012. Evaluation of the impact of the Green Academy programme and Case Studies. The Higher Education Academy, The Higher Education Academy, York. 
McCoshan, A., Martin, S., 2013. From strategy to implementation: the second evaluation of the Green Academy programme. The Higher Education Academy, https://www.heacademy.ac.uk/resources/detail/sustainability/green-academy [accessed May 2016].

McGibbon, C., Ophoff, J., Van Belle, J.-P., 2015. Our building is smarter than your building: The use of competitive rivalry to reduce energy consumption and linked carbon footprint. Knowledge Management \& E-Learning: An International Journal (KM\&EL) 6(4), 464-471.

Mohrman, S.A., Worley, C.G., 2010. The organizational sustainability journey: Introduction to the special issue. Organizational Dynamics 39(4), 289-294.

OECD, 2009. Sustainable Manufacturing and Eco-Innovation: Framework, Practices and Measurement Synthesis Report. https://www.oecd.org/env/consumptioninnovation/42957785.pdf [accessed July 2016].

Osborn, F., 1948. Our plundered planet. Faber and Faber, London.

Peters, T., Waterman, R., 1982. In search of excellence. Lessons from Americans Best Running Companies. New York: Harper \& Row.

Ramos, T.B., Caeiro, S., van Hoof, B., Lozano, R., Huisingh, D., Ceulemans, K., 2015. Experiences from the implementation of sustainable development in higher education institutions: Environmental Management for Sustainable Universities. Journal of Cleaner Production 106, 3-10.

Raworth, K., 2012. A Safe and Just Space for Humanity: can we live within the doughnut? Oxfam International Discussion Paper, http://www.oxfam.org/sites/www.oxfam.org/files/dp-a-safeand-just-space-for-humanity-130212-en.pdf [accessed July 2014].

Richardson, G.R., Lynes, J.K., 2007. Institutional motivations and barriers to the construction of green buildings on campus: A case study of the University of Waterloo, Ontario. International Journal of Sustainability in Higher Education 8(3), 339-354.

Rockström, J., Steffen, W., Noone, K., Persson, Å., Chapin, F., Lambin, E., Lenton, T., Scheffer, M., Folke, C., Schellnhuber, H.J., 2009. A safe operating space for humanity. Nature 461(7263), 472475.

Roorda, N., Rammel, C., Waara, S., Fra Paleo, U., 2009. Assessment instrument for sustainability in higher education. Edition, http://www.dho21.nl/documents/AISHEBook1.5.pdf [accessed November 2015].

Schein, E.H., 1985. Defining organizational culture, Classics of organization theory. pp. 490-502.

Schein, E.H., 1997. Organizational Culture and Leadership, 2nd ed. Jossey Bass, San Francisco.

Schensul, J.J., 2009. Community, culture and sustainability in multilevel dynamic systems intervention science. American Journal of Community Psychology 43(3-4), 241-256.

Schneider, B., Barbera, K.M., 2014. The Oxford Handbook of Organizational Climate and Culture. Oxford University Press, New York: NY.

Shiel, C., Filho, W.L., do Paço, A., Brandli, L., 2016. Evaluating the engagement of universities in capacity building for sustainable development in local communities. Eval. Program Plan. 54, 123-134.

Shriberg, M., 2002. Institutional assessment tools for sustainability in higher education: strengths, weaknesses, and implications for practice and theory. International Journal of Sustainability in Higher Education 3(3), 254-270.

Shriberg, M., Tallent, H., 2003. Beyond principles: implementing the Talloires Declaration. Greening of the Campus V: Connecting to Place, Ball State University, Muncie, Indiana, USA. 
Silver, H., 2003. Does a university have a culture? Studies in Higher Education 28(2), 157-169.

Smircich, L., 1983. Concepts of culture and organizational analysis. Administrative Science Quarterly 28, 339-358.

Smith, N.C., 2003. Corporate Social Responsibility: Whether or how? California Management Review 45(4), 52-76.

Sporn, B., 1996. Managing University Culture: An Analysis of the Relationship between Institutional Culture and Management Approaches. Higher Education 32(1), 41-61.

Stephens, J.C., Graham, A.C., 2010. Toward an empirical research agenda for sustainability in higher education: exploring the transition management framework. Journal of Cleaner Production 18(7), 611-618.

Tierney, W.G., 1988. Organizational culture in higher education: Defining the essentials. The Journal of Higher Education, 2-21.

Trencher, G., Bai, X., Evans, J., McCormick, K., Yarime, M., 2014. University partnerships for codesigning and co-producing urban sustainability. Global Environmental Change 28, 153-165.

UNESCO, 1990. The Talloires Declaration. Gland: UNESCO.

UNESCO, 2006. Framework for the UNDESD international implementation scheme. UNESCO Education Sector, Paris.

UW, 2016. University of Worcester sustainability policy. University of Worcester, https://www.worcester.ac.uk/discover/what-we-do-sustainability.html [accessed June 2017].

Velazquez, L., Munguia, N., Platt, A., Taddei, J., 2006. Sustainable university: what can be the matter? Journal of Cleaner Production 14(9-11), 810-819.

Verhulst, E., Lambrechts, W., 2014. Fostering the incorporation of sustainable development in higher education. Lessons learned from a change management perspective. Journal of Cleaner Production 106, 189-204

WCED, 1987. Our Common Future, World Commission on Environment and Development. Oxford University Press, Oxford, United Kingdom.

Weick, K.E., 1987. Organizational culture as a source of high reliability. California Management Review 29(2), 112-127.

Whitmarsh, L., 2011. Scepticism and uncertainty about climate change: dimensions, determinants and change over time. Global Environmental Change 21(2), 690-700.

Wilson, A.M., 2001. Understanding organisational culture and the implications for corporate marketing. European Journal of Marketing 35(3/4), 353-267.

Wright, T.S., 2007. Developing research priorities with a cohort of higher education for sustainability experts. International Journal of Sustainability in Higher Education 8(1), 34-43.

Wright, T.S.A., 2002. Definitions and frameworks for environmental sustainability in higher education. International Journal of Sustainability in Higher Education 3(3), 203-220. 


\section{REVIEWERS' COMMENTS:}

\section{REVIEWER \#1:}

The revised version of the paper has adequately addressed all the issues I raised during the first round of review. However, the following few technical issues still need to be addressed:

- The year of Talloires Declaration should be added in the introduction section

- Concerning the new title of section 2, "UNIVERSITY SUSTAINABILITY CULTURE IS A WICKED PROBLEM," since it is the authors' conceptualization of the issue as a "wicked problem," I think the title should read ".....AS A WICKED PROBLEM" instead of "...IS A WICKED PROBLEM"

- Table 1 should be on the top rather than the bottom.

- The appendix needs a title with the source of the information.

\section{RESPONSE}

The authors are grateful to reviewer \#1 for pointing out these technical issues, and each has been addressed in the accompanying revision. Further, the authors are grateful for reviewer \#1's support as well as their helpful insights and comments on the earlier version of the paper which have helped us improve the quality and contribution of our paper.

\section{REVIEWER \#2:}

Authors have addressed a majority of my comments on their earlier version. I think that this manuscript is now fully developed discussing a combined review of sustainability and organizational culture issues in $\mathrm{HEl}$ as well as proposing a framework and an initial application of it.

\section{RESPONSE}

The authors are grateful for reviewer \#2's support as well as their helpful insights and comments on the earlier version of the paper which have helped us improve the quality and contribution of our paper. 